\title{
IMPLEMENTASI FSM SEBAGAI RESPON OTONOM DAN ADAPTIF NPC PADA GAME “AWANG MENJELAJAHI KOTA TENGGARONG"
}

\author{
Azahari $^{1}$, Ivan Haristyawan ${ }^{2}$, Muhammad Jariansyah ${ }^{3}$ \\ STMIK Widya Cipta Dharma ${ }^{1,2,3}$ \\ Jl. M. Yamin No. 25, Samarinda, 75123 \\ Sur-el : azahari@wicdia.ac.id ${ }^{1}$, ivan@wicida.ac.id², mjahriansyah@gmail.com
}

\begin{abstract}
Development of the game towards a tourist promotion tool is very important. The game "Awang exploring the City of Tenggarong" is an android smartphone game that tells the story of a tourist / traveler named Awang who roams every tourist destination in the Tenggarong City. The development of this game uses multimedia development life cycle, starting from the concept, assembly, and testing. Artificial intelligence is also needed in the development of this game. Players will be accompanied by NPC (Non Player Character) in the form of a female tour guide. NPCs equipped with the Finite State Machine (FSM) model can guide players to go to each Tenggarong tourist attraction, and it can also provide information related to these tourist attractions. The final result of this research is a game that can be a media for tourism promotion in Tenggarong city.
\end{abstract}

Keywords: Games, Tourist Attraction, Awang, Tenggarong, NPC, Finite State Machine

\begin{abstract}
Abstrak : pengembangan game ke arah alat promosi wisata suatu daerah sangatlah penting. Game "Awang menjelajah Kota Tenggarong" adalah game smartphone android yang bercerita tentang turis/traveler bernama Awang yang menjelajah setiap destinasi wisata di kota Tenggarong. Pengembangan game ini menggunakan teknik pengembangan multimedia, dimulai dari tahap konsep, assembly sampai testing. Kebutuhan akan kecerdasan buatan pun dibutuhkan dalam pengembangan game ini. Pemain akan ditemani oleh NPC (Non Player Character) yang berbentuk wanita pemandu wisata. NPC yang dilengkapi dengan algoritma Finite State Machine (FSM) dapat memandu pemain untuk menuju ke setiap destinasi wisata Tenggarong, dan NPC juga dapat memberikan informasi terkait tempat wisata tersebut. Hasil akhir penelitian ini terciptanya sebuah game yang dapat menjadi media promosi wisata kota Tenggarong.
\end{abstract}

Kata kunci: Permainan, Wisata, Awang, Tenggarong, NPC, Finite State Machine

\section{PENDAHULUAN}

Game merupakan salah satu industri yang besar saat ini dan dapat menjadi alternatif hiburan untuk mengisi liburan maupun waktu luang dan menjadi kegiatan yang sangat menyenangkan bagi anak-anak maupun orang dewasa.[1,2]. Game awang menjelajah kota Tenggarong merupakan salah satu media yang akan digunakan dalam mempromosikan pariwisata yang ada di kecamatan Tenggarong dengan cara yang menyenangkan sehingga akan menarik minat masyarakat milenial untuk mengenal pariwisata yang ada di kecamatan Tenggarong sehingga diharapkan obyek pariwisata Tenggarong akan lebih dikenal masyarakatkan. penggunaan nama awang sendiri adalah merujuk pada tokoh Kutai Awang Long adalah panglima pada era Sultan Aji Muhammad Salahudin[3].

$$
\text { Untuk pembuatan game dapat }
$$
menggunakan beberapa cara, salah satunya dengan menggunakan game engine yang menawarkan paket pengembangan visual dan 
elemen-elemen lainnya yaitu software Unity $[1,2,4]$. Unity mendukung pembuatan game baik 3D maupun 2D pengembang di mudahkan dengan dapat menggunakan kembali elemenelemen yang telah dibuat sehingga akan lebih efisien dalam membangun game "Awang menjelajah kota Tenggarong”.

Salah satu jenis game yang digemari adalah game adventure. Game adventure dapat dikembangkan menjadi salah satu media promosi yang menyenangkan bagi masyarakat [5-6]. Gameadventure bertema wisata dapat menjadi media yang menarik untuk memperkenalkan macam-macam obyek wisata yang ada di Tenggarong melalui media game yang interaktif dan finite state machine digunakan dalam hal membuat interaksi pemain dengan (Non-Player Character)NPC. FSM terdiri dari serangkaian state yang menentukan keputusan. Setiap state dapat berpindah ke state lainnya jika memenuhi kondisi yang telah ditentukan sebelumnya [7-8].

Tujuan jangka panjang yang ingin dicapai dengan metode Finite State Machine karakter pendukung dalam game dibuat agar dapat berinteraksi dengan player sehingga akan membuat game ini lebih menarik. Target Khusus game Explore Tenggarong adalah pariwisata Tenggarong akan mudah diperkenalkan kepada masyarakat dengan media yang interaktif dan menarik.

Dengan metode Finite State Machine karakter pendukung dalam game dibuat agar dapat berinteraksi dengan player sehingga akan membuat game ini lebih menarik[7,9]. Finite State Machine digunakan karena sederhana, mudah dan fleksibel dalam penerapannya di dalam game sehingga memudahkan digunakan dalam membangun respon otonom dan adaptif [10] NPC pada game Awang menjelajah kota Tenggarong.

Dalam penelitian ini metode yang digunakan untuk membangun game adalah tahapan pengembangan multimedia mulai dari konsep, desain, material collecting, assembly, testing, distribution, kemudian melakukan testing kuesioner.

\section{METODOLOGI PENELITIAN}

Penelitian dilaksanakan melalui tahapan pengembangan multimedia sebagai berikut $[11,12]$ :

1. Studi literatur mengenai proses pembuatan edugame dan penerapan algoritma yang digunakan, serta mengumpulkan materialmaterial pembuatan game.

2. Proses pengembangan game dengan metode pengembangan multimedia, mulai dari desain sampai tahap assembly penerapan FSM ke dalam sistem game

3. Pemasangan aplikasi game ke dalam smartphone masyarakat dan pegawai dinas pariwisata yang menjadi tujuan aplikasi.

4. Melakukan beta testing berupa kuesioner kepada beberapa orang serta mengkaji dokumen-dokumen tersebut.

5. Menganalisis hasil kuesioner dan pengkajian kembali terhadap penerapan Finite State Machine dalam game.

Pendistribusian dan analisis kembali sampai hasil testing menghasilkan nilai presentasi yang memuaskan. Setiap tahapan 
dilakukan secara berurutan mulai dari langkah pertama sampai langkah terakhir, setiap langkah yang telah selesai dikerjakan harus dilakukan pengkajian ulang.

Perancangan dimana NPC akan mengekspresikan sebuah kondisi, yang terdiri Proses NPC mengarahkan dan memberikan penjelasan NPC pada obyek masing-masing obyek wisata yaitu Jam Bentong, Pulau Kumala, Museum Mulawarman, Planetarium. Yang memuat alur proses kondisi yang terjadi pada NPC (Non Player Character) Model logika FSM pada agen karakter Jenny dapat dilihat pada Gambar 2.

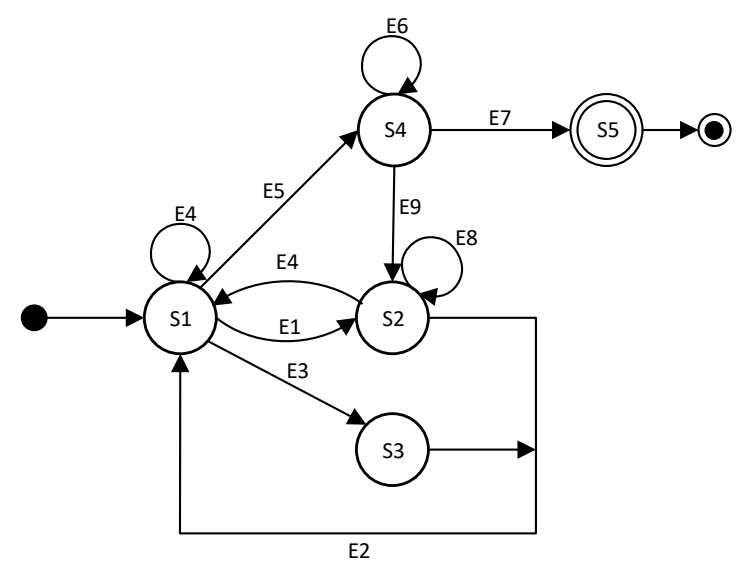

Gambar 2. Rancang model FSM pada NPC

Keterangan Gambar 2 dan Tabel 1.

State :

S1. Ekspresi Diam/Idle

S2. Berlari

S3. Memberi Peringatan

S4. Wisata

S5. Piala

Event :

E1. Pemain Mendekat ke NPC

E2. Pemain jauh dari NPC

E3. Pemain berada sangat jauh dari NPC

E4. NPC berada dititik lokasi wisata

E5. Pemain mengajak NPC berbicara di lokasi wisata

E6. Pemain belum menyelesaikan semua misi wisata

E7. Pemain telah menyelesaikan semua misi wisata

E8. Pemain berada di jangkauan NPC

E9. NPC Menuju ke wisata selanjutnya
Model pada Gambar 1NPC berada pada keadaan diam state S1 apabila Player mendekat maka dia akan berlari menuju obyek wisata yaitu memasukki state S2 dan apabila pemain jauh dari NPC maka dia akan kembali ke state S1 diam, apabila pemain terlalu jauh NPC akan memberikan peringatan pada state S3 kemudian saat pemain hanya dalam keadaan jauh peringatan akan hilang dan kembali ke state S1, apabila NPC telah berada dilokasi wisata dia akan masuk ke state S1 apabila dia dalam keadaan berlari S2, saat pemain mengajak NPC berbicara di obyek wisata maka NPC akan menjelaskan dan memberikan misi pada pemain apabila pemain belum menyelesaikan misi maka NPC akan menuju ke obyek wisata selanjutnya, apabila pemain telah menyelesaikan misi maka NPC akan memberikan piala. Setiap model state dan event ini dijabarkan dalam tabel transisi pada tabel 1.

Tabel 1. Transisi agen karakter

\begin{tabular}{llllllllll}
\hline & \multicolumn{8}{c}{ Input } \\
\cline { 2 - 9 } & E1 & E2 & E3 & E4 & E5 & E6 & E7 & E8 & E9 \\
\hline S1 & S2 & & S3 & S4 & & & & & \\
S2 & & S1 & & & & & & S2 & \\
S3 & & S1 & & & & & & & \\
S4 & & & & & & S5 & S6 & & S2 \\
S5 & & & & & & & & & \\
\hline
\end{tabular}

3. HASIL DAN PEMBAHASAN

"Game Awang menjelajah kota Tenggarong" adalah sebuah permainan berbasis Android untuk mengenalkan obyek wisata kota Tenggarong dengan cara yang menyenangkan 
dan menarik untuk kalangan milenial. Nama Awang sendiri digunakan karena merupakan tokoh yang ada di Kutai pada zaman Sultan Aji Muhammad Salahudin yaitu merujuk pada Panglima Awang Long [3]. Permainan ini memiliki aturan permainan yang menampilkan konten yang dirancang untuk pengguna 13 tahun ke atas.

Pada game ini menggunakan metode FSM pada NPC(Non Player Character) sebagai proses otonom dan adaptif sehingga karakter dapat bergerak sendiri secara otonom. Konsep FSM pada NPC adalah NPC berada pada keadaan diam apabila Player mendekat maka dia akan berlari menuju obyek wisata yaitu memasuki dan apabila pemain jauh dari NPC maka dia akan kembali ke diam, apabila pemain terlalu jauh NPC akan memberikan peringatan pada kemudian saat pemain hanya dalam keadaan jauh peringatan akan hilang dan kembali ke, apabila NPC telah berada di lokasi wisata dia akan masuk ke apabila dia dalam keadaan berlari , saat pemain mengajak NPC berbicara di obyek wisata maka NPC akan menjelaskan dan memberikan misi pada pemain apabila pemain belum menyelesaikan misi maka NPC akan menuju ke obyek wisata selanjutnya, apabila pemain telah menyelesaikan misi maka NPC akan memberikan piala. Karakter NPC dapat dilihat pada Gambar 3.

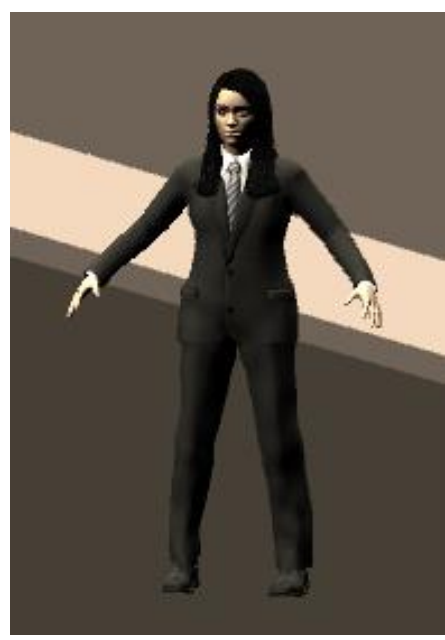

Gambar 3. NPC(Non Player Character)

Permainan memiliki beberapa pilihan wisata yang masing-masing memiliki misi yang berbeda, pemain dapat memilih untuk menuju salah satu obyek wisata di antara 4 .obyek wisata yaitu Jam Bentong, Pulau Kumala, Museum Mulawarman, dan Planetarium. saat pemain sampai di obyek wisata pemain akan mendapat penjelasan mengenai obyek wisata tersebut dan pemain diarahkan untuk menyelesaikan misi yang diberikan oleh NPC. Pada obyek wisata Jam Bentong pemain akan memainkan permainan puzzle mencocokkan gambar, setelah menyelesaikan permainan di obyek Jam Bentong pemain tidak dapat kembali memainkan permainan puzzle di Jam Bentong dan pemain harus memilih salah satu objek wisata lagi untuk menyelesaikan semua misi di masing-masing obyek wisata. Pada obyek wisata Pulau Kumala pemain akan mendapat penjelasan dari NPC mengenai obyek wisata Pulau Kumala tersebut dan pemain di arahkan oleh NPC untuk menyelesaikan misi puzzle menyusun potongan gambar Dan obyek wisata Museum Mulawarman pemain akan mendapat penjelasan dari NPC mengenai informasi Museum Mulawarman dan 
di arahkan menyelesaikan misi puzzle menyusun potongan gambar pada obyek wisata Planetarium pemain akan mendapatkan penjelasan mengenai obyek wisata Planetarium oleh NPC dan di arahkan untuk menyelesaikan misi puzzle geser gambar Setelah pemain menyelesaikan empat misi pada masing-masing obyek wisata permainan telah menyelesaikan seluruh permainan mendapatkan piala dan credits scene akan ditampilkan.

Tampilan pada game "Awang menjelajah kota Tenggarong”. Dapat dilihat pada Gambar 4. tampilan halaman awal game tampilan ini akan ditampilkan menu-menu pada awal memainkan game yaitu menu mulai, credit, dan keluar. Tombol mulai digunakan untuk pemain memulai permainan dan memasuki scene wisata, tampilan menu awal.

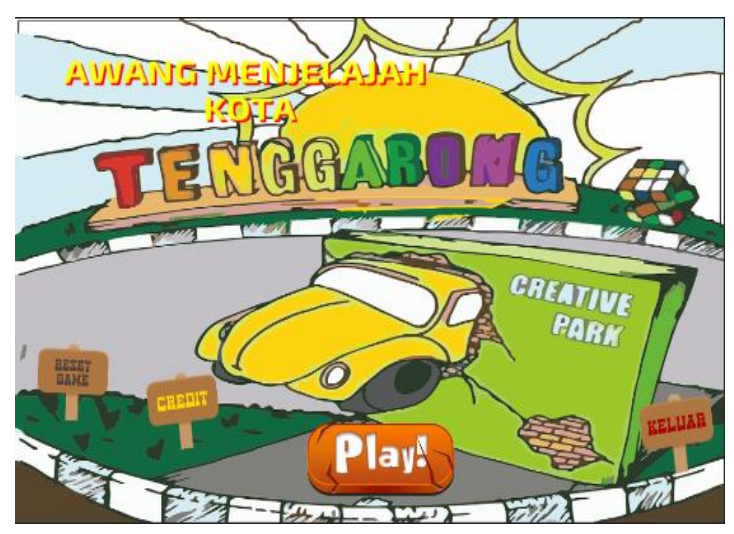

Gambar 4. Interface menu utama game "Awang Menjelajah kota Tenggarong"

Gambar 5 Tampilan Scene Wisata terdapat joystik, tombol obrolan, tombol lompat dan peta dan di-scene wisata juga di tampilkan obyekobyek 3D dari obyek wisata Tenggarong.

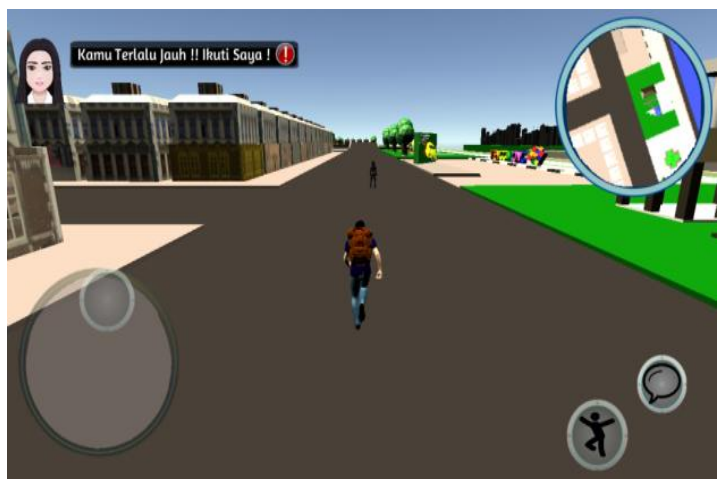

Gambar 5. Tampilan Halaman Scene wisata

Pada halaman wisata pemain akan di arahkan oleh NPC untuk menuju tempat-tempat wisata yang ada di kota Tenggarong, pada awal permainan NPC akan mengarahkan pemain menuju ke wisata jam bentong dan NPC akan menjelaskan tentang objek wisata Jam bentong lalu pemain akan menyelesaikan misi puzzle pada objek wisata jam bentong dapat dilihat pada Gambar 6.

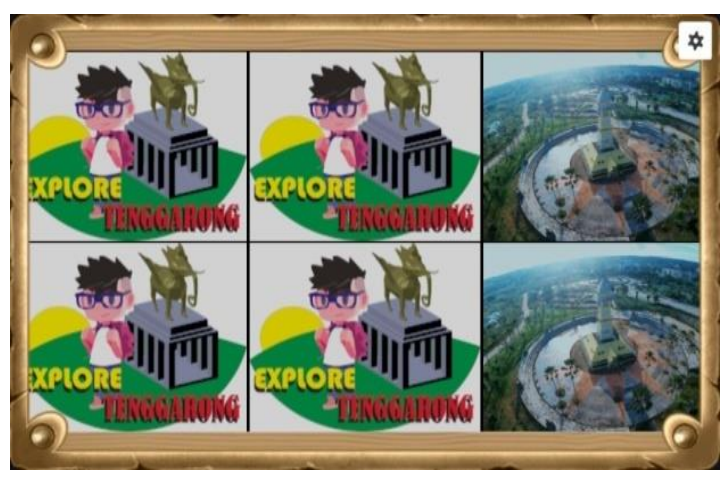

Gambar 6. Tampilan halaman misi Puzzle Jam bentong

Setelah pemain menyelesaikan misi pada jam bentong NPC selanjutnya akan mengarahkan pemain menuju objek wisata pulau Kumala dan menjalankan misi tampilan misi pulau kumala dapat dilihat pada Gambar 7. 


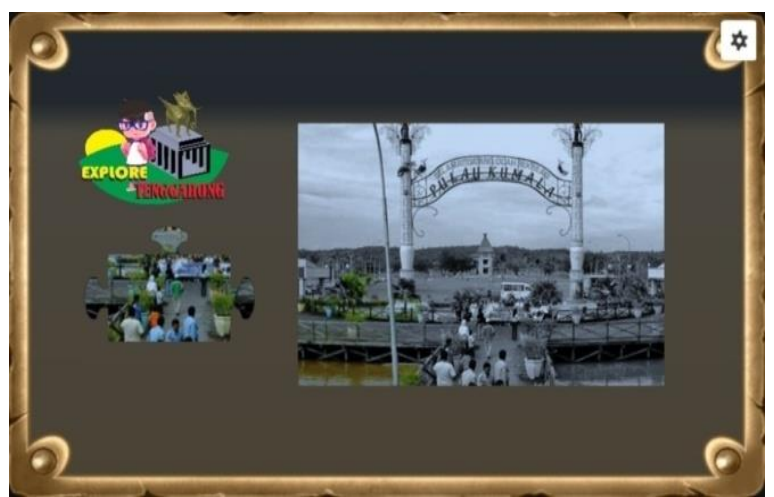

Gambar 7. Tampilan halaman misi Pulau Kumala

Setelah pemain menyelesaikan misi pada pulau kumala NPC selanjutnya akan mengarahkan pemain menuju objek wisata pulau Museum Mulawarman dan menjalankan misi tampilan misi museum Mulawarman dapat dilihat pada Gambar 8.

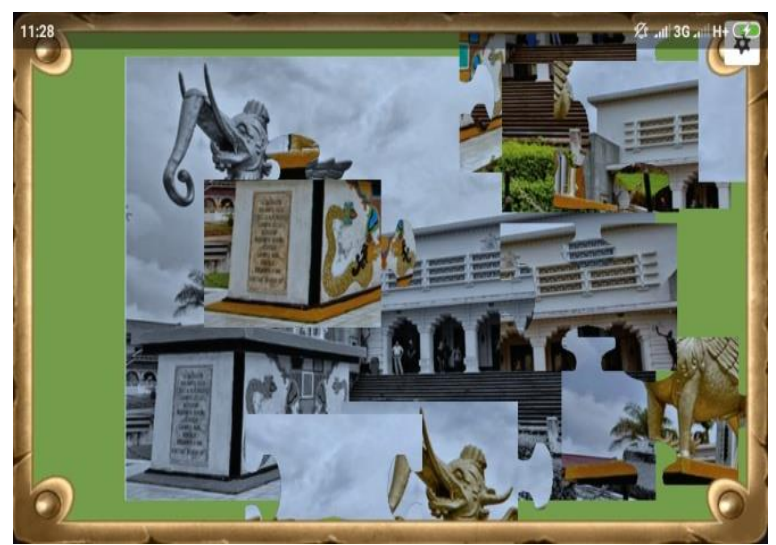

Gambar 8. Tampilan halaman misi Museum Mulawarman

Setelah pemain menyelesaikan misi pada Museum Mulawarman NPC selanjutnya akan mengarahkan pemain menuju objek wisata planetarium dan menjalankan misi tampilan misi Planetarium dapat dilihat pada Gambar 9

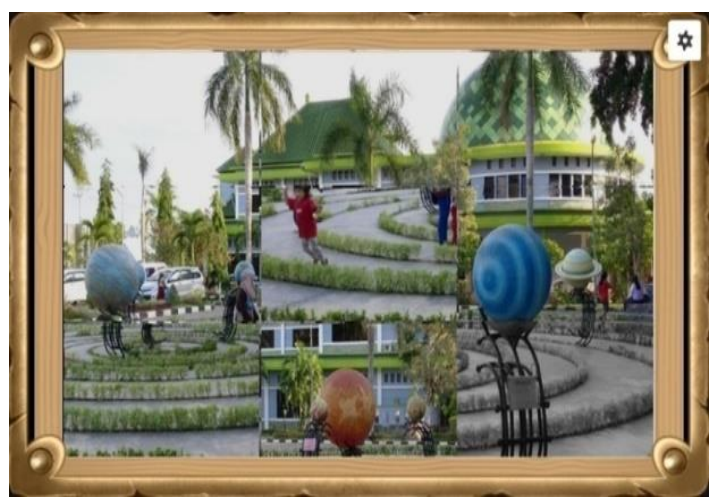

Gambar 9. Tampilan halaman misi

Planetarium

Proses implementasi penerapan Finite State Machine untuk melihat perubahan perilaku NPC terhadap permainan yang sedang berjalan. pembuatan state-state dengan setiap perubahan state yang terjadi dapat dilihat sebagai berikut:

\section{1) State Diam/Idle}

Pada State diam/idle apabila pemain berada di luar jangkauan NPC . dapat dilihat pada lingkaran merah Gambar 10.

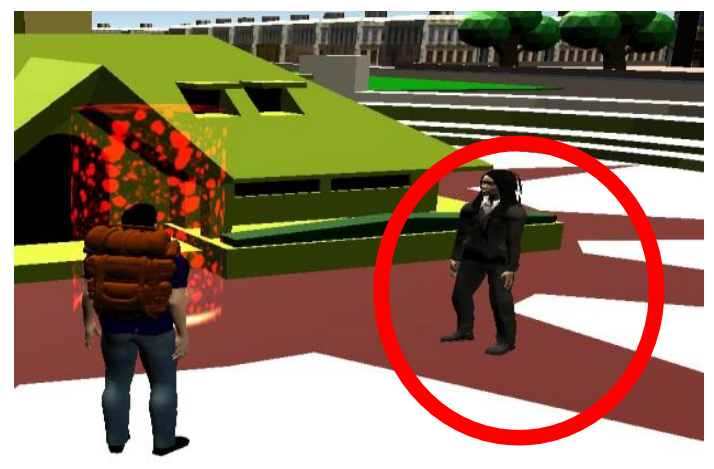

Gambar 10. State Diam

2) State berlari menuju Wisata

Pada saat pemain mendekat pada NPC maka NPC akan berlari menuju tempat wisata. Dapat dilihat pada lingkaran merah Gambar 11. 


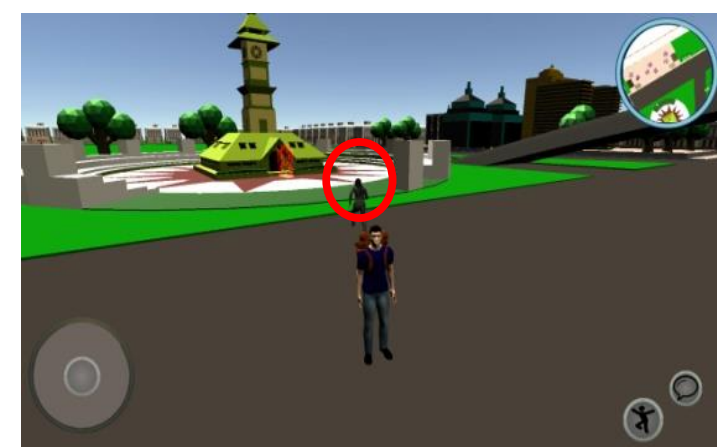

Gambar 11. State Berlari

\section{3) State Wisata}

Pada State Wisata pemain memasuki titik merah dan mengajak NPC berbicara maka NPC akan menjelaskan informasi Wisata lalu memberikan misi kepada pemain. Dapat dilihat pada lingkaran merah Gambar 12

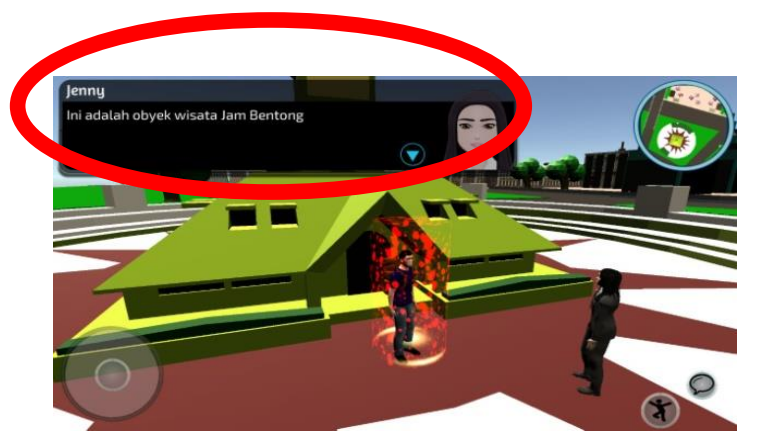

Gambar 12. State Wisata

\section{4) State Peringatan}

Apabila pemain berada terlalu jauh dari jangkauan NPC maka NPC akan memberikan peringatan. Dapat dilihat pada lingkaran merah Gambar 13.

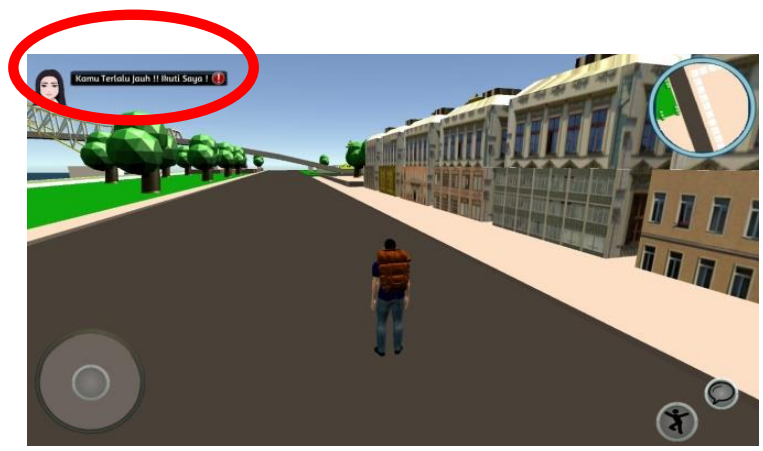

Gambar 13. State Peringatan

\section{5) State Piala}

Pada state terakhir pemain telah menyelesaikan semua misi permainan maka NPC akan memberikan piala penghargaan. Dapat dilihat pada lingkaran merah Gambar 14.

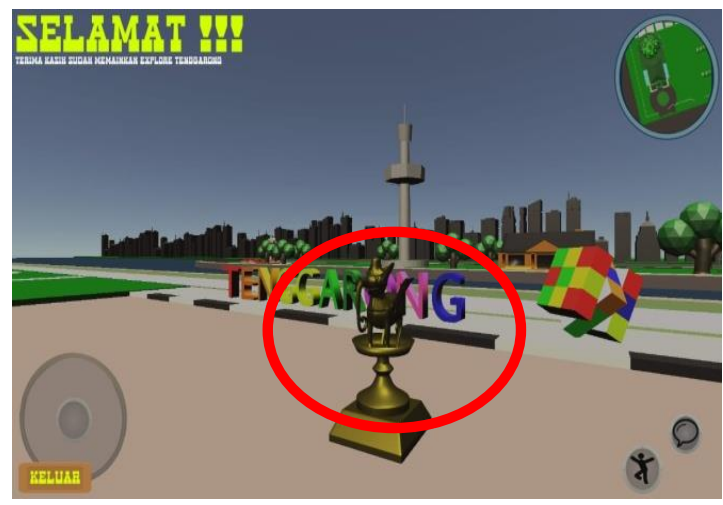

\section{Gambar 14. State Piala}

Proses pengujian beta merupakan uji coba sebuah aplikasi secara live di dalam suatu lingkungan yang tidak dapat dikontrol oleh pengembang[13]. Setelah pembuatan game selesai dan sudah dapat dimainkan maka dilakukan pengujian beta dengan memberikan game kepada 10 orang dan memberikan kuesioner kepada mereka serta meminta pendapat dan saran untuk pengembangan game ke depannya. Hasil testing ditampilkan pada tabel 2.

Berdasarkan tabel 2 maka hasil kuesioner yang di dapatkan dari jawaban responden adalah:
1. Sangat Kurang
$: 1 \mathrm{x}-1=-1$
2. Kurang
: $0 \times 0=0$
3. Cukup
: $29 \times 1=29$
4. Bagus/Menarik
$: 31 \times 2=62$
5. Sangat Bagus/Menarik : $39 \times 3=117$ 
Tabel 2. Hasil Beta Testing

\begin{tabular}{|c|c|c|c|c|c|}
\hline \multirow{2}{*}{ Daftar Pertanyaan } & \multicolumn{5}{|c|}{ Jawaban } \\
\hline & 1 & 2 & 3 & 4 & 5 \\
\hline Judul Game & 0 & 0 & 1 & 5 & 4 \\
\hline $\begin{array}{c}\text { Informasi Wisata } \\
\text { pada game }\end{array}$ & 0 & 0 & 4 & 3 & 3 \\
\hline $\begin{array}{l}\text { Responsif dengan } \\
\text { perangkat yang } \\
\text { digunakan }\end{array}$ & 0 & 0 & 3 & 4 & 3 \\
\hline Tingkat kesulitan & 0 & 0 & 3 & 4 & 3 \\
\hline Desain Karakter & 0 & 0 & 1 & 0 & 9 \\
\hline $\begin{array}{l}\text { Fungsi Tombol- } \\
\text { tombol }\end{array}$ & 0 & 0 & 4 & 4 & 2 \\
\hline Fungsi joystik & 0 & 0 & 4 & 6 & 0 \\
\hline $\begin{array}{l}\text { Desain obyek } \\
\text { wisata }\end{array}$ & 0 & 0 & 0 & 2 & 8 \\
\hline $\begin{array}{c}\text { Gambar-gambar } \\
\text { pada game }\end{array}$ & 0 & 0 & 5 & 3 & 2 \\
\hline Musik pada game & 1 & 0 & 4 & 0 & 5 \\
\hline Total & 1 & 0 & 29 & 31 & 39 \\
\hline
\end{tabular}

Dari pertanyaan yang di ajukan dihitung dan ditarik kesimpulan bahwa dari 10 responden keseluruhan nilai didapatkan hasil akhir (1) yaitu $69 \%$.

$$
\begin{aligned}
& Y=\frac{x}{n} 100 \% \\
& Y=(-1+0+29+62+117) / 300=0,69
\end{aligned}
$$

Dari nilai 5 yaitu sangat bagus persentasenya sebesar 39\%, nilai 4 yaitu bagus persentasenya sebesar $31 \%$, nilai cukup yaitu persentasenya $29 \%$, dan nilai jelek persentase sebesar 0\%,dan sangat jelek dengan persentase $1 \%$.

\section{KESIMPULAN}

Berdasarkan uraian yang telah dipaparkan, ditarik kesimpulan pengembangan game Awang menjelajah kota Tenggarong melalui tahapan konsep, desain, pengumpulan bahan, assembly, pengujian dan pendistribusian. Kemudian fungsi
FSM (Finite State Machine) pada game Awang menjelajah kota Tenggarong yaitu sebagai respon NPC saat ada kondisi tertentu. Di dalam game ini pemain dapat mengetahui informasi mengenai pariwisata Tenggarong melalui respons yang diberikan NPC

Pengujian beta menunjukkan tingkat kepuasan penguji yang memainkan game ini yaitu $1 \%$ memilih sangat kurang, $0 \%$ memilih kurang, 29\% memilih cukup, $31 \%$ memilih bagus/menarik, 39\% memilih Sangat bagus dan dari keseluruhan dihitung sehingga mendapatkan poin $69 \%$ dari 10 pertanyaan oleh 10 responden.

Untuk pengembangan aplikasi selanjutnya diharapkan dapat ditambahkan objek wisata yang memuat seluruh kabupaten Kutai Kartanegara dan pada masing-masing objek wisata pemain dapat memasuki objek wisata secara langsung untuk melihat benda-benda yang ada $d$ dalamnya.

\section{UCAPAN TERIMA KASIH}

Direktorat Riset dan Pengabdian Masyarakat Direktorat Jenderal Penguatan Riset dan Pengembangan Kementerian Riset dan Teknologi/ Badan Riset dan Inovasi Nasional sesuai dengan Kontrak Penelitian Tahun Anggaran 2020. 


\section{DAFTAR PUSTAKA}

[1] Tridhonanto, al. Optimalkan potensi anak dengan game. Jakarta: PT. Elex media komputindo, 2011.

[2] Napitupulu, Darmawan. Perancangan program game $P C$ hack \& slash berbasis multimedia menggunakan unity 3d. 2017.

[3] Sulistyo, Kiftiawati; Mappatang, Nasrullah. Antitesis Hero's Journey Dalam Novel Senopati Awang Long Karya Herman salam. Jurnal melayu sedunia, 2019.

[4] Pamoedji, Andre Kurniawan., maryuni, ridwan sanjaya. Mudah membuat game augmented reality (ar) dan virtual reality (vr) dengan unity $3 d$. Elex media komputindo, 2017.

[5] Haryanto, Hanny. Pendidikan moral dengan menggunakan sistem reward dalam game imersif. J. Techno. Com, 2010.

[6] Wardhani, Retno; Yaqin, moh husnul. Game dasar-dasar hukum islam dalam kitab mabadi'ul fiqh jilid i. Jurnal teknika, 2013.

[7] Rahadian, Miftah Fauzan; Suyatno, addy; maharani, septya. Penerapan metode finite state machine pada game "the relationship". 2017.

[8] Andriansyah, Rifaldi Teguh. penggunaan metode fsm untuk musuh pada game mushroom hunter. Jati (jurnal mahasiswa teknik informatika), 2018.

[9] Hidayat, Eka wahyu; Rachman, andi nur; azim, muhammad fauzan. Penerapan finite state machine pada battle game berbasis augmented reality. J. Edukasi dan penelit. Inform, 2019.

[10] Asmiatun, s., \& Putri, a. N. Belajar membuat game $2 d$ dan $3 d$ menggunakan unity. Sleman : deepublish, 2017.

[11] Kyaw, A.s. PETERS, C. And Swe, t.n. Unity 4.x game ai programming. Packt publishing , ltd. Birmingham. 2013.

[12] Binanto, Iwan. Multimedia Digital Dasar Teori dan pengembangannya. Yogyakarta: andi, 2010.

[13] Agarwal, B. B., Tayal, s. P., \& Gupta, m. Software engineering and testing. Jones \& bartlett learning. 2010. 